\title{
Los espacios que habitan las mujeres en Capitães da areia de Jorge Amado*
}

\author{
Héctor Andrés Rojas ${ }^{* *}$
}

\begin{abstract}
Resumen
El presente artículo analiza, desde una perspectiva de género, los espacios que habitan las mujeres, para lo cual se centra en los distintos personajes femeninos que aparecen en Capitães da Areia (1937) de Jorge Amado, los que son representados con poder de decisión sobre sus vidas en la medida en que poseen un capital económico. Dentro de las mujeres representadas destaca la figura de Dora, la única niña que se integra el bando. Cuando Dora llega al grupo, los niños ya han buscado estrategias compensatorias para no estar en una posición vulnerable, pero el costo de este crecimiento forzado es la carencia de ideales mayores a la sobrevivencia. Entonces Dora, que si bien reproduce algunas características comúnmente asociadas a las mujeres, como ser madre de algunos niños y esposa de Pedro Bala, todo esto a nivel simbólico, es quien posibilita la formación política de los Capitães da Areia, ya que mientras está con ellos logra que vuelvan a ser niños y crezcan. Entonces, su presencia, más que compensar la marginalidad, la remedia.

Palabras Clave: Infancia, mujeres, espacio, marginalidad.
\end{abstract}

\footnotetext{
* Recibido: abril 2017. Aceptado: julio 2017.

La primera versión del presente artículo formó parte mi tesis "Compensar, remediar y transformar la marginalidad en Capitanes de la arena de Jorge Amado: Un recorrido desde el deseo al quehacer político", con la obtuve el grado académico de Magíster en Literatura Latinoamericana en la Universidad Alberto Hurtado durante el año 2014. Dicha investigación se enmarcó dentro del proyecto FONDECYT de iniciación 11100266, "El ojo y la oreja: Sobre algunos motivos en la poesía y poética brasileña del Siglo XX" del profesor Fernando Pérez Villalón.

** Universidad Alberto Hurtado. Santiago, Chile. Email: hector.rojas1985@gmail.com
} 


\section{Abstract \\ The spaces inhabited by women in Capitães da Areia of Jorge Amado}

The present article analyzes, from a gender perspective, the spaces inhabited by women. For this reasons, this article focuses on the different female characters that appear in Capitães da Areia (1937) by Jorge Amado, who are represented with decision power over their lives as they have an economic capital. Dora, the only girl that integrates the band, stands out among the women represented in the novel. When Dora arrives to the group, children have already sought compensatory strategies to avoid being in a vulnerable position, but the cost of this forced growth is the lack of ideals greater than survival. Then Dora, who at a symbolic level reproduces some characteristics commonly associated with women, such as being the mother of some children and wife of Pedro Bala, is the one that makes possible the political formation of Capitães da Areia, because while she is with them she achieves to make them kids again and grow up. Then, her presence, rather than compensating for marginality, remedies it.

Keywords: Chilhood, women, space, marginality.

\section{Jorge Amado y Capitães da Areia}

Jorge Amado tuvo una extensa producción literaria desde los años 30 hasta la década del 90 del siglo XX. La obra de la primera parte de su producción se relaciona estrechamente con una tendencia regionalista y la escritura de la década de 1930 en Brasil. Esta tendencia surge en diálogo con la Semana de Arte Moderno, realizada entre el 11 y el 18 de febrero de 1922 en São Paulo, donde predominó un tono celebratorio de lo moderno. A propósito de este evento, cuatro años más tarde, en 1926, el sociólogo Gilberto Freyre organizó el Primer Congreso de Regionalistas del Nordeste, instancia en la que lanzó el Manifiesto Regionalista de 1926 "o qual se tornou, posteriornente, um documento historico e literario do Regionalismo nordestino" (Azevedo, 1983: 92). Así, la semana de Arte Moderno genera una apertura en la importancia otorgada al arte como medio de representación, que luego, en el regionalismo se vuelve una crítica al cosmopolitismo de la vanguardia y la literatura producida en los grandes centros urbanos del país. 
Tal como señala Carlos Alberto Azevedo, este manifiesto busca revalorizar las clases subalternas como los descendientes de africanos y los mestizos "incorporando-as ao Modernismo regionalista. folclórico, libertino e 'populista"” (1983: 92). Por otra parte, en el plano histórico-social la novela nordestina da cuenta del inicio de un periodo de industrialización en la década del 30 con el surgimiento de un nuevo e importante factor del cuadro político brasileño: "a massa do proletariado urbano, manobrada por Getúlio Vargas, que demonstrou, na época, possuir boa visão das perspectivas históricas e de como manipular o proletariado emergente" (Azevedo, 1983: 95).

Hay que dejar en claro, que si bien es posible entender la escritura regionalista de los años 30 en respuesta a las ideas modernizadoras de la época, este tipo de escritura también es el resultado de la maduración de la literatura regionalista de los años 20 :

tomando por amostra a literatura, verificam-se nela alguns traços que, embora característicos do período aberto pelo movimento revolucionário, são na maioria "atualizações" (no sentido de "passagem da potência ao ato") daquilo que se esboçara ou definira nos anos 20. É o caso do enfraquecimento progressivo da literatura acadêmica; da aceitação consciente ou inconsciente das inovações formais e temáticas; do alargamento das "literaturas regionais" à escala nacional; da polarização ideológica. (Cândido "A Educação", 1989: 185)

La escritura de los años 30, además de caracterizarse por poseer un tono regionalista, poseía una visible orientación marxista "E assim como o espiritualismo atingiu largos setores não-religiosos, o marxismo repercutiu em ensaístas, estudiosos, ficcionistas que não eram socialistas nem comunistas, mas se impregnaram da atmosfera 'social' do tempo" (Cândido "A Educação", 199:189). Estos temas son también sintomáticos de una época en un proceso políticamente modernizador: "em certos países, como o Brasil, quanto mais cresce a riqueza, mais aumenta a péssima distribuição dos bens. Portanto, podemos dizer que os mesmos meios que permitem o progresso podem provocar a degradação da maioria" (Cândido "O direito", 2007: 169). Cândido da cuenta de que esta tendencia en la escritura regionalista no solo busca retratar una zona que ha sido postergada del imaginario oficial, sino que también busca reinstalar como un problema sus inequidades: "É aí que se situa a literatura social, na qual pensamos quase exclusivamente quando se trata de uma realidade tão política e humanitária quanto a dos direitos humanos, que partem de uma análise do universo social e procuram retificar as suas iniquidades" (Cândido "O direito", 2007: 180). 
Este artículo se propone estudiar desde los estudios literarios la presencia de las mujeres en la novela de Jorge Amado. Debemos considerar que es una novela protagonizada por hombres, donde las mujeres ocupan roles secundarios y funcionales a la acción de los protagonistas. Su presencia, si bien no conduce la acción de la obra, responde a lógicas de poder interesantes de analizar. La única mujer que ocupa un rol más protagónico dentro de la novela es Dora, la única niña que logra incorporarse al grupo de niños, por lo que ocupará la mayor parte de nuestro análisis. Su presencia, sin embargo, está limitada exclusivamente a una de las tres partes que conforman Capitães $d a$ Areia $^{l}$. Las demás mujeres que aparecen en la historia tienen apariciones breves a lo largo de la novela, pero, de igual forma, nos otorgarán elementos para poner en tensión los espacios que habitan, las ficciones domésticas y también la posibilidad que tienen de elegir sobre su sexualidad. De esta forma, nos proponemos analizar esta novela con perspectiva de género para contrinuir a los estudios literarios que se han realizado al respecto, principalmente centrados en la infancia.

La hipótesis de lectura será doble. En primer lugar, la presencia de Dora al interior del grupo los ayuda a remediar su condición de vulneración inicial que los mantenía al margen de las discusiones políticas de su entorno. Dora será madre, hermana, amante y amiga de los niños que solo se tenían los unos a los otros y que, antes de su presencia, compensaban su condición marginal en los afectos que se expresaban y en la conformación del bando como una familia. Dora es fundamental en el proceso de crecimiento de conscientización política de los niños. Por otro lado, como segunda hipótesis y dependiente de la primera, por lo que ocupará una parte menor en el presente artículo, las formas de habitar de las distintas mujeres, si bien reproducen roles domésticos o sexualizados, como en el caso de la prostitución, conforman formas de autodeterminación doméstica en la medida en que ejercen roles de poder al interior de sus vidas, lo que estará vinculado a la poseción económica.

A finales del siglo XIX, con la abolición oficial de la esclavitud, el advenimiento de la República y las grandes migraciones por el progresivo proceso de migración e industrialización, Brasil comenzaba a transformarse en una sociedad "moderna e higiénica". Estos cambios entre finales del diecinueve e inicios del veinte fueron designadas como Belle Époque Brasileña (Scott, 2012:16). Si bien este proceso de modernización generó algunos cambios en

\footnotetext{
${ }^{1}$ A lo largo del presente artículo se citará la obra a estudiar en portugués, lengua en la que fue escrita. Adicionalmente se incluye a pie de página la traducción del texto realizado por Estela Dos Santos. Cada cita, en portugués o español, tiene la referencia a la edición consultada y a la paginación correspondiente.
} 
la estructura familiar, no fueron profundos: "mantiene a mesma hierarquia com relação aos papéis masculinos e femininos, com o homem à cabeça da casa e da família e a mulher como subalterna e dependente" (Scott, 2012:17). En definitiva, aparece la pregunta por la mujer, pero en gran medida para dar cuenta del prodominio de lo masculino en lo político.

Capitães da Areia de Jorge Amado narra la historia de un grupo de niños huérfanos que viven en comunidad y al margen de la sociedad en Salvador de Bahía. La novela estructuralmente está conformada por veintisiete capítulos, distribuidos en tres partes: "Sob a lua num velho trapiche abandonado", "Noite da grande paz, da grande paz dos teus olhos" y "Canção da Bahia, canção da liberdade" 2 . La primera parte de la novela da cuenta de la situación en la que viven los personajes: en un depósito abandonado donde antes llegaba el mar y que ahora está repleto de arena. El puerto y el depósito son descritos con nostalgia, porque se extraña una época gloriosa económicamente: "Não mais atracaram na sua ponte os veleiros que iam partir carregados. Não mais trabalharam ali os negros musculosos que vieram da escravatura. Não mais cantou na velha ponte uma canção um marinheiro nostálgico" (Amado, 2012: $25)^{3}$. Salvador de Bahía es presentado como un lugar de miseria, donde viven esto niños sin protección de padres. Los niños son descritos como libres de maldad, justificando la necesidad de robar a diario para comer: "A cidade e as casas, metonimicamente substituem as pessoas... A miséria das crianças é, desse modo, representada pela proloneza do trapiche" (Gómez, 1994: 50). Por tanto, podremos pensar que las condiciones en las que se conforma la ciudad influyen en las personas que la habitan.

La segunda parte del libro, "Noite da grande paz, da grande paz dos teus olhos", es diferente al resto del libro porque está marcada por la presencia de Dora, la mujer más importante en la novela y la única que llega a integrar el grupo de los Capitães da Areia. Su presencia sirve como preparación para lo que desarrollará luego en cuanto a la conformación de una identidad política situada en Salvador de Bahía, logrando remediar esta condición marginal de la que hemos hablado.

En la tercera parte del libro, "Canção da Bahia, canção da liberdade", termina por producirse una transformación en la vida de los personajes, que

\footnotetext{
2 "Bajo la luna, en un viejo depósito abandonado", "En la noche de la gran paz, de la gran paz de tus ojos" y "Canción de Bahía, canción de libertad".

3 "Ya no atracan en su puente los veleros que iban a marcharse cargados. Ya no trabajan allí los negros forzudos que venían de la esclavitud. Ya no canta su canción en el viejo puente ningún marinero nostálgico" (Amado, 1984: 25).
} 
ya habían encontrado herramientas para compensar y remediar su condición marginal. Estos niños-adultos se integran de diferente manera en una sociedad, no sin dejar ver los vicios y las desigualdades: Pedro Bala se inicia en la lucha política, Professor se va a Río de Janeiro a estudiar pintura, Pirulito entra a la Iglesia. No es casual que el título de esta tercera parte hable de la canción, porque la revitalización del pueblo que fue azotado por la miseria y la viruela se expresa a través de la música, elección de Jorge Amado para representar la identidad de la ciudad:

A revolução chama Pedro Bala como Deus chamava Pirulito nas noites do trapiche. É uma voz poderosa dentro dele, poderosa como a voz do mar, como a voz do vento, tão poderosa como uma voz sem comparação. Como a voz de um negro que canta num saveiro o samba que Boa-Vida fez:

Companheiros, chegou a hora... (Amado, 2012: 258)

En definitiva, la necesidad de los personajes de enfrentar su condición marginal se extrapola a una necesidad de hacerse cargo de la estructura social en la que están insertos de diversos modos, ya sea manteniéndose al margen o luchando para modificarla. Es así que los Capitanes tendrán un rol importante en la huelga de trabajadores de Salvador de Bahía.

Otra posibilidad es lo que plantea Luis de Melo Diniz, quien comparó la novela de Amado con la conocida novela Oliver Twist de Charles Dickens ${ }^{5}$ y propuso un contexto escritural, histórico y social semejante: "a do abandono e a da violência contra a criança, em meio a dois importantes momentos de desenvolvimento do Capital, o da Revolução Industrial, na Inglaterra, e o do início do processo de industrialização no Brasil" (Diniz, 2009: 1). Esto permitiría comprender la tematización de la infancia como un medio para la denuncia de una condición social, ya que los procesos de industrialización, tanto en Inglaterra un siglo antes, como en Brasil, tendrían como contraparte una dura realidad en la que los niños serían los principales afectados.

\footnotetext{
4 “La revolución llama a Pedro el Bala como Dios llamaba a Pirulito en las noches del depósito. Es una voz poderosa, poderosa como la voz del mar, como la voz del viento, tan poderosa como una voz que no se puede comparar con nada. Como la voz de un negro cantando el samba de Buena-Vida:

$<$ Companheiros, chegou a hora >" (Amado, 1984: 278).

${ }^{5}$ Esta novela publicada en 1837, exactamente cien años antes que la obra de Amado, comparte con ella características como el protagonismo infantil, la crisis económica y el contexto de producción.
} 
Érica Antunes Pereira para analizar la condición de marginales de los personajes de esta novela, recurre a la conocida pregunta de $\operatorname{Spivak}^{6}$, sobre si puede hablar el sujeto subalterno. Para Pereira los mecanismos escogidos por Jorge Amado tendrían que ver con mostrar un horizonte marginalizado:

não é a sua voz que fala ou é invocada, mas sim a expressão de um horizonte marginalizado pela experiência dominadora e que, ao materializar-se em texto, de alguma forma efetiva um resgate a memórias e histórias pretensamente ocultas e/ou apagadas. Como afirmei, não é a voz do subalterno a falar, mas sim a encenação de uma voz que se quer dele. (Pereira, 2012: 58)

El rol del Estado en la novela se puede apreciar especialmente por el intento de controlar a los niños marginados llevándolos al orfanato. Este elemento de la ficción de Jorge Amado tiene un correlato con el contexto de la época en la que aparece esta novela. Ivone Maria Xavier de Amorim Almeida señala respecto al Código de Menores de 1927 que éste:

Instituído em 12 de outubro, previa que os menores de 14 anos declarados penalmente irresponsáveis eram encaminhados a reformatórios e sujeitos a medidas reeducativas, através de rígida disciplina, sob vigilância do Juiz. A atitude delinquente dessas crianças e adolescentes, segundo a leitura do Código da época, era decorrente "da omissão e da transgressão da família em seus direitos básicos”. (citado en Nunes, 2012: 4)

La misma definición de infancia debe ser precisada: "No século XX, o lugar social reservado às sinhazinhas e às meninas pobres seria questionado com a entrada em cena de una nova noção de infância" (Arend, 2012: 68), de acuerdo con la cual "as pessoas entre 0 e 18 anos passaram a ser consideradas 'seres em formação', tanto do ponto de vista corporal quanto psicológico" (Arend, 2012: 70). Silvia Fávero Arend indica que a partir de este cambio de percepción sobre la infancia, el sentido de la paternidad y maternidad se alteró y adquirió gran importancia (2012: 70). Es importante reconocer la condición de abandono en la que están los niños como una crítica a la sociedad moderna y al concepto de familia, lo que sumado a la preocupación del

\footnotetext{
${ }^{6}$ Gayatri Spivak se pregunta: “¿puede hablar el sujeto subalterno?”. Esta pregunta que en principio se resuelve como una imposibilidad, está trabajada por a nivel simbólico: En el texto una niña de 16 o 17 años, Bhuvaneswari Bhaduri se suicida en un modesto departamento en el norte de Calcuta. La niña, sujeto subalterno, logra hablar atentando contra sí misma; lo que es representado en su suicidio ejecutado mientras estaba menstruando, para desprenderse de un entorno que no le permitía tener una voz discursiva: "trato de 'hablar' convirtiendo su cuerpo en un texto de mujer/ escritura" (Spivak, 2009: 122). La autora señala que conoce la historia a través de conexiones familiares.
} 
Estado por normar la infancia, cobra en Capitães da Areia un tono paródico respecto a la política de la época. La condición de abandono de los niños es una crítica a la sociedad moderna y al concepto de familia, lo que sumado a la negativa de los niños por vivir en el orfanato, mostrándolo como un sistema represivo y cruel, intensifican el carácter crítico de la visión de Jorge Amado respecto a las políticas sobre infancia del Brasil en estas décadas.

En los años 30 existía una preocupación política en Brasil por la delincuencia infantil, que era objeto de amplios debates (Gomes: 2005: 28), porque parecía ser un punto de conflicto social posible de abordar. Getúlio Vargas promulgó una ley como protector de los niños:

Em 10 de novembro de 1937 foi promulgada a Constituição da República dos Estados Unidos do Brasil, pelo Presidente Getúlio Vargas que tinha, no seu governo, a intenção de modernizar o país com a instalação do Estado Novo -momento de transformação político-sociais- privilegiando a infância e a juventude. Através das políticas estabelecidas por meio do seu autoritarismo político é que Getúlio Vargas passa a ser visto como "protetor" das crianças.

(Gomes, 2005: 35)

¿Qué es lo que produce esta situación de marginación? Una respuesta posible es considerar los factores económicos y sociales, además de la descomposición de la familia: "Dentre vários fatores responsáveis pelo abandono do menor estão os econômicos e sociais, principalmente no contexto moderno. Assim, os juristas apontam: a decomposição da família e a dissolução do poder paterno e materno como pontos centrais dessa situação" (Gomes, 2005: 70). Esta crisis de los modelos gatilla el surgimiento de un tipo de identidad que necesariamente debe hacerse cargo de esta disolución de modelos sociales confiables, lo que llega a concretarse con la búsqueda de la transformación política.

Gomes ve en la pandilla el elemento clave para el crecimiento de los individuos que lo conformaban: "A convivência familiar assegura a seus membros a continuidade do seu projeto de vida, sua idealização pessoal, pois, dessa forma, há um crescimento interior e uma realização profissional" (2005: 80). Sin embargo, la manera diversa en la que esos proyectos de desarrollan, manteniéndose al margen de la sociedad moderna, permite suponer que en realidad el bando como familia es solo un medio de compensar y remediar la condición marginal en la que viven. El verdadero cambio estará gatillado por la importancia de lo político como conformación de identidad. 


\section{Los espacios que habitan las mujeres}

\subsection{Las mujeres en la obra de Jorge Amado}

Sobre la representación de las mujeres en la obra de Jorge Amado, Brivio realiza un interesante estudio cuantitativo sobre la cantidad de mujeres aparecidas en las obras del escritor bahiano, donde muestra, por ejemplo, una inclinación a la mayor representación de las mujeres de clase trabajadora (2005: 126). También da cuenta de una preferencia a la aparición de personajes sin estado civil definido (2005: 127). La mayoría de estas mujeres son blancas (2005: 129).

Capitães da Areia propone una distribución de los espacios que habitan los distintos personajes, donde es posible identificar una suerte de naturalización de las posibilidades de participación en la ciudad de la mujer delimitada a ciertas funciones, que revisaremos en el presente artículo. A primera vista, podemos entender que se la incluye en la historia contada, pero esta inclusión tiene límites claramente identificables. Es por esto que será de gran importancia estudiar los espacios que habitan las mujeres en la novela, los roles que asumen y las acciones que protagonizan. Es así como tendremos mujeres que aparecen en alguna parte de esta novela de Jorge Amado sexualizadas a los ojos de los hombres, para quienes la dominación de los cuerpos femeninos será un medio de creación de un discurso de hombría, que permite competir entre quienes conforman los Capitães da Areia. Habrá mujeres que podrán permitirse tener un deseo sexual, quienes, tal como veremos más adelante, tienen en común tener un espacio físico y material que les pertenece. Por otro lado, habrá otras mujeres que parecen portar poder, pero este se limita a las decisiones domésticas, espacio restringido en el que mandan. También habrá mujeres que porten un discurso religioso, lo que se justifica en las tradiciones culturales de origen africano, que aportan una mirada particular de las formas de relaciones entre divinidad y creencia. Por último está el personaje de Dora, la única niña que llega a formar parte de los Capitães da Areia, asumiendo diferentes roles comúnmente asociados a las mujeres y travistiéndose para poder formar parte del grupo. En definitiva, el rol de las mujeres estará estrechamente vinculado con la posesión económica y los espacios que habitan.

Una característica común que tienen todas las mujeres en la novela es que están solas. No aisladas de la sociedad. Solas como mujeres, sin un vínculo con otras mujeres que les permita establecer lazos de solidaridad y cooperación. Silvia Federici analiza la figura e la mujer en el proceso en el que se instala el capitalismo, en el cual la mujer pierde sus relaciones colectivas: 
Si tenemos también en consideración que en la sociedad medieval las relaciones colectivas prevalecían sobre las familiares, y que la mayoría de las tareas realizadas por las siervas (lavar, hilar, cosechar y cuidar los animales en los campos comunes) eran realizadas en cooperación con otras mujeres, nos damos cuenta de que la división sexual del trabajo, lejos de ser una fuente de aislamiento, constituía una fuente de poder y de protección para las mujeres. Era la base de una intensa socialidad y solidaridad femenina que permitía a las mujeres plantarse en firme ante los hombres, a pesar de que la Iglesia predicase sumisión y la Ley Canónica santificara el derecho del marido a golpear a su esposa (2015: 44).

La respuesta, en el caso de las mujeres en Capitães da Areia no es la reproducción de las prácticas colectivas de cooperación entre mujeres del medioevo, que era la forma evocada por Silvia Federici. Lo que nos encontramos es una forma de sobrevivencia a pesar de la plena vigencia de las lógicas del capital. Las mujeres están solas y logran, en algunos casos, encontrar espacios de poder doméstico precisamente en la protección que les otorga el acceso al dinero.

\subsection{La mãe-de-santo ${ }^{7}$}

Un elemento interesante de Capitães da Areia, tiene que ver con la elección de niños como protagonistas de la obra. Si bien el proceso natural de crecimiento y formación propios de la edad permite realizar el recorrido de propuesto por Amado en su novela, vale la pena entender la medida en que la infancia era un tema de discusión en el Brasil de las décadas del 20 y 30. Los niños necesitan de una protección familiar y en ese proceso de búsqueda de medios de compensación, aparecerán personajes que puedan representar desde los distintos cultos religiosos una alternativa a esa carencia: "esses me-

\footnotetext{
${ }^{7}$ El rito del candomblé es iniciado por una mãe-de-santo, rol que es ocupado principalmente por mujeres. Sin embargo, Ruth Landes señala que el lugar de la mãe-de-santo también lo ocupan en algunos casos los homosexuales pasivos: "uma tendência; um gradual aumento do número de mães-de-santo nos candomblés mais tradicionais e um aumento do número de "homossexuais passivos' nos candomblés de caboclo" (Landes, 2002: 24). Si bien esto no es algo que esté narrado en Capitanes de la arena, es interesante rescatarlo a propósito de las prácticas homosexuales que se narraban entre los niños del arenal, donde la infancia entendida como un carnaval permitía temporalmente la suspensión de las categorías de género. El candomblé, según lo señalado por Landes, tendría esa misma característica. También existe una sacerdotisa menor: "A mãe é auxiliada por sacerdotisas chamadas filhas- de- santo - filhas porque as treinou ou as 'fez', de criaturas de cerne e ouso, vasos dedicados as manifestações dos deuses”' (Landes, 2002: 321). A pesar de la presencia de algunos hombres, como mencionamos hace un momento, se debe reconocer la enorme proporción en que las mujeres son responsables del culto religioso.
} 
ninos sentiram falta dessa proteção familiar e buscaram, quando criança, na figura do padre e da mãe-de-santo o que perderam, mesmo que mais tarde, quando adultos, saiam dessa estrutura e se dispersem, pois já não mais precisam dessa proteção" (Gomes, 2005: 78). Estos personajes, dan cuenta de una sociedad diversa, no solo en el culto, sino también en lo racial, como sucede con el padre, que representa a una iglesia de origen europeo y blanca, mientras que la mãe-de-santo es la voz de un culto de origen africano, quien en el personaje de Don'Aninha, no solo se conforma en oposición simbólica al padre José Pedro, también representa un tipo de mujer.

Bárbara Bush al estudiar a las esclavas del Caribe encuentra que tuvieron un impacto decisivo en la población blanca. En el caso de Capitães da Areia, si bien se sitúa en Brasil, ocurre el mismo tipo de interacción cultural entre mujeres negras y blancas, donde las primeras logran impactar "a través de sus actividades como curanderas, videntes, expertas en prácticas mágicas y la «dominación» que ejercían sobre las cocinas y dormitorios de sus amos (Bush, 1990)" (Citado en Federici, 2015, 204).

El caso de la mujer negra y criolla tiene particularidades, ya que al carecer de poseción económica, además de la posición marginal de ser mujer, debe revitalizar algunas prácticas de cooperación:

No sólo crearon las bases de una nueva identidad femenina africana, sino también las bases para una nueva sociedad comprometida - contra el intento capitalista de imponer la escasez y la dependencia como condiciones estructurales de vida - en la reapropiación y la concentración en manos femeninas de los medios fundamentales de subsistencia, comenzando por la tierra, la producción de comida y la transmisión ínter-generacional de conocimiento y cooperación (Federici, 2015: 205).

La historia de Don'Aninha sucede en la lógica antes descrita. Se sabe que es la mãe-de-santo, que sí tiene vínculo con otras mujeres -a diferencia de las mujeres que analizaremos a continuación-, que además de relaciona con los Capitães da Areia a través de un vínculo de cuidado y protección mutuo, pero su historia escapa de la narración, se sugiere y no se desarrolla, queda en el entredicho, ya que la historia de concentra en los niños que viven en el arenal. 


\subsection{La mujer objeto}

Un personaje que aparece brevemente en la novela es una niña que es violada por Pedro Bala en el arenal, escena que permite comprender la construcción del deseo del personaje:

Chorava, e Pedro Bala tinha pena, mas o desejo estava solto dentro dele. Então propôs ao ouvido da negra (e fazia cócegas a língua dele):

- Só boto atrás.

- Não. Não.

- Tu fica virgem igual. Não tem nada.

- Não. Não, que dói.

Mas ele a acarinhava, uma cócega subiu pelo corpo dela. Começou a compreender que se não o satisfizesse como ele queria, sua virgindade ficaria ali. E quando ele prometeu (novamente sua língua a excitava no ouvido) (Amado, 2012: 90) ${ }^{8}$

Se dice de ella que es negra y que su manera de caminar recuerda una danza. Ella es la primera presencia femenina que aparece sexualizada a los ojos de los niños, ya que debido a su condición de niña y negra, es más vulnerable a la estructura social de género en la que está inmersa:

Sacudiu seu corpo de menino como se sacode animal jovem ao ver a fêmea, e com passo rápido se aproximou mulher que agora entrava no areal. A areia chiava sob os pés e a mulher notou que era seguida. Pedro Bala podia vê-la bem quando ela passava sob os postes: era uma negrinha bem jovem, talvez tivesse apenas quinze anos como ele. Mas os seios saltavam pontiagudos e as nádegas rolavam no vestido, porque os negros mesmo quando estão andando

\footnotetext{
${ }^{8}$ Lloraba y Pedro sentía pena, pero el deseo estaba suelto dentro de él. Entonces le propuso al oído (y con la lengua le hacía cosquillas).

-Sólo por atrás.

-No. No.

-No te pasa nada. Sigues virgen igual.

-No. No, que duele.

Pero seguía acariciándola y ella sintió todo el cuerpo convulsionado. Comprendió que si no lo satisfacía como pedía, su virginidad terminaría allí. Y cuando le prometió (nuevamente su lengua la excitaba desde el oído) (Amado, 1984: 95).
} 
naturalmente é como se dançassem... Pensava em derrubar a negrinha sobre a areia macia, em acariciar seus seios duros (talvez seios de virgem, sempre seios de menina), em possuir seu corpo quente de negra (Amado, 2012: 87) ${ }^{9}$.

En el caso de la descripción de esta niña, hay una doble sexualización. No solo es su condición de mujer la que la sexualiza, sino que también el hecho de ser negra la que reafirma ese rol entendido como natural. Esta relación de doble subalternidad, racial y de género, tiene sentido al entender la manera en que el género se vincula con espacios sociales. Esto puede comprenderse a la luz del trabajo de Teresa De Lauretis, quien analiza las prácticas culturales desde el concepto de tecnología del sexo: "como un conjunto de técnicas para maximizar la vida que han sido desarrolladas y desplegadas por la burguesía desde finales del siglo XVIII para asegurar su supervivencia de clase y su hegemonía permanente" (De Lauretis,1996:19). Lo curioso, si nos tomamos de esta última afirmación, es que quien ejerce el poder en esta práctica basada en el argumento de género también es un sujeto subalterno, un niño abandonado. No obstante esto último, vale la pena considerar estas técnicas de género, que

involucran la elaboración de discursos (clasificación, medición, evaluación, etc.) acerca de cuatro figuras privilegiadas u objetos de conocimiento: la sexualización de los niños y del cuerpo femenino, el control de la procreación y la psiquiatrización del comportamiento sexual anómalo como perversión (De Lauretis, 1996: 19).

Frente a esta misma situación de la niña negra en el arenal, el deseo de Pedro Bala es descrito como algo irracional, incluso animal: "E o desejo cresceu dentro de Pedro Bala, era um desejo que nascia da vontade de afogar a angústia que o oprimia. Pensando nas nádegas reboleantes da negrinha não pensava na morte de seu pai defendendo o direito dos grevistas, em Omolu pedindo vingança na noite de macumba" (Amado, 2012: 87) ${ }^{10}$. Aquí aparece

\footnotetext{
9 "Sacudió su cuerpo de niño como se sacude un animal joven al ver una hembra y con paso apresurado se acercó a la mujer que ahora entraba en el arenal. La arena crujía bajo sus pies y la mujer se dio cuenta de que la seguía. Pedro el Bala la podía ver bien cuando pasaba bajo los focos de luz: era una negrita muy joven, quizá de unos quince años, como él. Pero los pechos puntiagudos le saltaban y las nalgas se movían bajo la falda. Porque el andar de los negros es como una danza... Pensaba en tirar a la negrita sobre la arena blanda, en acariciar sus senos duros (tal vez senos de virgen, siempre senos de muchacha), en poseer su cuerpo caliente de negra" (Amado, 1984: 92).

10 "era un deseo que nacía de la voluntad de ahogar la angustia que lo oprimía. Si pensaba en las nalgas bamboleantes de la negrita no pensaba en la muerte de su padre defendiendo los derechos de los huelguistas, en Omolu pidiendo venganza en la noche de la macumba" (Amado, 1984: 92).
} 
también una angustia latente derivada de los problemas sociales y culturales en los que está inmerso, respecto a los cuales la sexualidad serviría para evadirse, que hacia la última parte de la novela emergerán como una solución posible ante una sociedad desigual en un proyecto utópico. Incluso, luego de la violación, las ideas que lo atormentan regresan:

E tinha vontade de se jogar no mar para se lavar de toda aquela inquietação, a vontade de se vingar dos homens que tinham matado seu pai, o ódio que sentía contra a cidade rica que se estendia do outro lado do mar, na Barra, na Vitória, na Graça, o desespero da sua vida de criança abandonada e perseguida, a pena que sentia pela pobre negrinha, uma criança também.

"Uma criança também" - ouvia na voz do vento, no samba que cantavam, uma voz dizia dentro dele (Amado, 2012: 92) ${ }^{11}$.

Esa voz interior es el espíritu revolucionario en el personaje, que podrá desarrollarse en la novela, como veremos más adelante. En esta parte de la historia el proyecto de igualdad no está maduro. Todavía la desigualdad de género aprendida lo lleva a abusarla, aun cuando ambos son niños.

\subsection{El espacio asignado a las decisiones de las mujeres}

Hay dos personajes femeninos que tienen en común ser de una clase económica acomodada y ser presentadas como dueñas de las decisiones que se toman al interior de su hogar. La primera es doña Laura, que es la señora de la casa donde trabajaba la madre de Dora antes de morir. En el espacio de su hogar tiene una posición económica que la hace no estar en el mismo nivel de subalternidad de otras mujeres. De algún modo, en el universo de su hogar, ella ocupa un rol dominante, que seguramente no podría replicarse fuera de ese espacio. En su casa puede tomar decisiones como no querer contratar a Dora, sin haberle consultado a un hombre. Lo mismo sucede con el personaje de doña Ester, la mujer que es engañada por el Sem-Pernas para que los Capitanes de arena le roben. Ella decide recibirlo como si fuera su hijo, en su hogar puede tomar ese tipo de decisiones y en su caso el motivo es la sustitución

\footnotetext{
11 "Y tenía ganas de tirarse al mar para quitarse tanta angustia, las ganas de vengarse de los hombres que habían matado a su padre, el odio que sentía contra la ciudad rica que se extendía al otro lado del mar, por la Barra, la Vitória, la Graça, la desesperación de su vida de chico abandonado y perseguido, la pena que sentía por esa pobre negrita, una niña también.

'Una niña también', oía en la voz del viento, en el samba que cantaban, una voz dentro de él” (Amado, 1984: 97).
} 
del hijo que perdió, dejando en claro que está limitada al espacio familiar y que sus acciones provienen de esta necesidad burguesa de una familia. Es esta necesidad la que los Capitães da Areia aprovechan para robarle.

El Sem-Pernas llegó a una casa de doña Ester, una mujer que había perdido a su hijo para robarle, busca conmoverla y lo consigue: "Se eu quisesse me metia aí com esses meninos ladrão. Com os tal de Capitães da Areia. Mas eu não sou disso, quero é trabalhar. Só que não agüento um trabalho pesado. Sou um pobre órfão, tou com fome" (Amado, 2012: 117) ${ }^{12}$. La estrategia del personaje es explotar el deseo de maternidad de esa mujer: "Mas a senhora não estava indecisa. Estava era se lembrando seu filho, que tinha morrido com a idade daquele e que ao morrer matara toda a sua alegria e a do marido" (Amado, 2012: 117) ${ }^{13}$. Este deseo de maternidad es la que la hizo vulnerable y dejó entrar a su casa al Sem-Pernas, quien se hizo llamar Augusto, como el hijo muerto de doña Ester: "Meu filho também se chamava Augusto... Morreu quando tinha assim o seu tamanho... Mas entre, meu filho, vá se lavar para comer" (Amado, 2012: 117) ${ }^{14}$. A pesar de que el Sem-Pernas se sintió conmovido y tardó en avisar a los demás niños para que ejecutaran el robo, finalmente cumplió con su misión en esa casa de gente acomodada.

Es interesante considerar que estas mujeres tienen algún espacio de decisión. Nancy Armstrong considera que en la ficción doméstica aparece un espacio de desarrollo emocional de las mujeres. "De esta forma, la ficción doméstica pudo representar una forma alternativa de poder político sin dar la apariencia de estar rebatiendo la distribución de poder que representaba tal como la historia mandaba" (Armstrong, 1991: 46), ya que en el panorama general la mujer no tiene espacio de expresión de sus preocupaciones o emociones, que como hemos mencionado, es espacio que los Capitães da Areia utilizaron para obtener beneficios.

En la familia burguesa el hombre es el representante del Estado

el encargado de disciplinar y supervisar las nuevas «clases subordinadas», una categoría que para los teóricos políticos de los siglos XVI y XVII (por ejemplo Jean Bodin) incluía a la esposa y sus hijos (Schochet, 1975). De ahí la

\footnotetext{
12 "Si yo quisiera me podría ir con esos chicos ladrones, con los Capitanes de la arena. Pero yo no soy ladrón, quiero trabajar. Pero no aguanto un trabajo fuerte. Soy un pobre huérfano, tengo hambre" (Amado, 1984:124)

13 "La señora no estaba indecisa. Estaba recordando a su hijo que había muerto más o menos de la misma edad y que al morir se había llevado toda su alegría y la de su marido" (Amado, 1984: 124).

14 “Mi hijo también se llamaba Augusto... Se murió cuando tenía más o menos tu edad ... Pero pasa, hijo mío, anda a lavarte para comer" (Amado, 1984: 125)
} 
identificación de la familia con un micro-Estado o una micro-Iglesia, así como la exigencia por parte de las autoridades de que los trabajadores y trabajadoras solteros vivieran bajo el techo y las órdenes de un solo amo. Dentro de la familia burguesa, se constata también que la mujer perdió mucho de su poder, siendo generalmente excluida (Federici, 2015, 174).

Por esta razón hemos querido fijarnos en los espacios domésticos en los que las mujeres pueden acceder a cierto niño de poder. Para esto debemos considerar que "el ascenso de la mujer doméstica como un acontecimiento fundamental de la historia política no equivale, como podría parecer, a presentar términos contradictorios, sino a identificar la paradoja que da forma a la cultura moderna" (Armstrong, 1991: 15). Siendo por tanto, un espacio de apertura como de encierro. Recordemos que las mujeres, a excepción de la mãe-de-santo, están privadas de vínculos comunitarios, siendo sus espacios de poder también sus celdas.

Hasta el momento hemos revisado la situación de la niña del arenal que fue mirada como objeto de deseo y violada por Pedro Bala. Luego, pudimos revisar la situación de dos mujeres que habitan el espacio del hogar y muestran sus roles maternos, en el caso de doña Ester la debilidad que la hizo vulnerable. Ahora bien, ninguno de estos personajes femeninos que hemos revisado ha mostrado un deseo sexual propio, ¿por qué razón?, seguramente porque no tienen un lugar propio en el cual desarrollar su deseo.

Vimos que doña Ester y doña Laura tenían una posición social económica mayor que los demás personajes, lo que les permitía en el espacio del hogar tener algún nivel de autoridad -aunque paradójico-, pero al mismo tiempo no había indicios de deseo sexual, como si la maternidad y la sexualidad fueran formas opuestas de lo femenino, lo que tiene una respuesta práctica porque roles como la maternidad demandan tiempo y pueden terminar por limitar a una mujer.

\subsection{La paradoja del dinero}

Habría que pensar en otro tipo de representaciones de lo femenino. Hay otros dos personajes en la novela que, a diferencia de los personajes analizados anteriormente, no están vinculados a la maternidad, pero sí tienen independencia económica. Además tienen un espacio propio, una casa, y precisamente son estos personajes los que sí expresan deseos sexuales independientes del deseo sexual masculino. 
El primero de estos personajes es Dalva, que tiene un romance con Gato, uno de los niños del arenal. Ella es una prostituta que se encariña con él luego de descubrir que el flautista con quien salía antes la engañaba. Fue el mismo Gato quien le contó: "ele tá grudado com outra, sabe? Também eu disse as boas aos dois. E depois pelei a bruaca" (Amado, 2012: 43) ${ }^{15}$. Entonces Gato se empezó a quedar a dormir con ella, incluso a recibir dinero de su parte: "Vem, bichinho bom. Que malandro não vai sair daí! Vou te ensinar tanta coisa, meu cachorrinho" (Amado, 2012: 43) ${ }^{16}$, lo que logra constituir una relación afectiva.

¿Qué implicancias tiene que Dalva tenga solvencia económica? Es lo que le otorga dignidad y libertad de expresar su deseo. Esta situación se presenta como una paradoja. Por un lado que sea prostituta la vuelve un objeto del sistema, la convierte en mercadería que se puede pagar, pero luego ese dinero le otorga independencia económica y autonomía para desear sexualmente y expresarlo, como ocurre en su relación con Gato.

Es el dinero el que vuelve poderoso a quien lo posee. Por el mismo motivo es ella quien toma las decisiones en esa relación. Es así como cuando decide partir, Gato la acompaña en la búsqueda de un mejor lugar para trabajar. Esto ocurre cuando por todo Brasil se sabe que la producción de cacao está en alza económica: "Os navios chegam a Ilhéus carregados de mulheres. Mulheres que vêm da Bahia, de Aracaju, o mulherio todo de Recife, mesmo do Rio de Janeiro. Os gordos coronéis olham das pontes a chegada das mulheres. Morenas, loiras e mulatas" (Amado, 2012: 234) ${ }^{17}$. Frente a ese horizonte de expectativas, Dalva también decide partir. En ese momento Gato tenía 18 años y la acompaña: "Mano, vou para Ilhéus. A patroa vai cavar a vida. Eu vou com ela. Sou capaz de enricar" (Amado, 2012: 235) ${ }^{18}$. Hacia el final de la novela se sabe que esa relación se terminó cuando Gato vuelve a Salvador de Bahía.

Personajes como Dalva dan cuenta desde su particularidad del sistema de género, que aunque se diferencia entre culturas, siempre se relaciona con lo político y lo económico: "A pesar de que los significados cambien en cada

\footnotetext{
15 "él está acostado con otra, ¿sabes? Le dije unas buenas a los dos. Y después le robé a esa loca" (Amado, 1984: 44).

16 "Ven, bichito querido. ¡Qué chulo va a salir de ahí! Yo te voy a enseñar un montón de cosas, cuzquito" (Amado, 1984: 44).

17 "Los barcos llegan a Ilhéus cargados de mujeres. Mujeres que vienen de Bahía, de Aracaju, de Recife, hasta de Río de Janeiro. Los gordos coroneles [hombres ricos] observan desde los puentes la llegada de las mujeres. Morenas, rubias y mulatas" (Amado, 1984: 251).

18 "Hermano, me voy para Ilhéus. La patrona se va a ganar la vida allá. Y yo me voy con ella. Capaz que me hago rico" (Amado, 1984: 252).
} 
cultura, un sistema sexo-género está siempre íntimamente interconectado en cada sociedad con factores políticos y económicos" (De Lauretis, 1996: 11). Por eso resulta llamativo el caso de Dalva, porque la prostitución le permite acceder a un nivel de independencia mayor, al mismo tiempo que la mantiene en la posición de sometimiento ante el deseo y el acceso económico masculino, al nivel de que llega a trasladarse a zonas con mejores perspectivas económicas. No podemos ignorar que "la construcción cultural de sexo en género y la asimetría que caracterizan a todos los sistemas de género a través de las culturas (aunque en cada una en un modo particular) son entendidos como ligados sistemáticamente a la organización de la desigualdad social" (De Lauretis, 1996: 11) Entonces podemos resolver la paradoja de Dalva, lo que sucede con ella es que ocupa una posición intermedia. Socialmente sigue en el margen, sigue siendo una prostituta, pero en sus relaciones personajes logra posicionarse como la portadora de las decisiones, porque tiene solvencia económica.

Si consideramos que "en la sociedad capitalista, el cuerpo es para las mujeres lo que la fábrica para los trabajadores asalariados varones: el principal terreno de su explotación y resistencia" (Federici, 2015, 28), Dalva ofrece un ejemplo de la relación paradojal del sometimiento de su cuerpo al capital y la utilización a su favor del deseo masculino para su propio beneficio.

Un segundo personaje interesante de analizar, al igual que como ocurría con Dalva, es el de la solterona a quien el Sem-Pernas seduce para luego robarle:

Gato contou que a solteirona era cheia do dinheiro. Era a última de uma família rica, andava pelos quarenta e cinco anos, feia e nervosa. Corria a notícia de que tinha uma sala cheia de coisas de ouro, de brilhantes e joias acumuladas pela família através de gerações. Pedro Bala pensou que era uma coisa capaz de dar um bocado de dinheiro (Amado, 2012: 229) ${ }^{19}$.

Frente a ese dato de Gato, enviaron al Sem-Pernas, de la misma manera en que lo hicieron antes a la casa de doña Ester. Cuando llegó "A solteirona não tirava os olhos dele. Um menino... Não era a bondade que falava dentro dela. Era a voz do sexo que dava seus últimos latidos" (Amado, 2012: 229) ${ }^{20}$. Aquí

\footnotetext{
19 “Gato contó que la solterona estaba llena de plata. Era la última descendiente de una familia rica y andaba por los cuarenta y cinco años, fea y nerviosa. Decían que tenía una sala repleta de objetos de oro, de brillantes y de joyas acumuladas por la familia a través de generaciones. Pedro el Bala pensó que era una oportunidad para conseguir una cantidad de dinero" (Amado, 1984: 245).
}

20 “La solterona no le quitaba los ojos de encima. Un chico ... No era bondad lo que sentía. Era la voz del 
es posible ver que su condición de no casada, es decir, sin el sometimiento a una figura patriarcal ni a las limitaciones de la maternidad, es lo que permite la aparición del deseo. La relación con el Sem-Pernas fue difícil, se involucraban sentimientos y deseos: "Durante o dia responde mal a Joana, diz brutalidades, a solteirona chora. Ele a chama de vitalina, diz que vai embora. Ela he dá dinheiro, pede que ele fique. Mas não é pelo dinheiro que ele fica. Fica porque o desejo o retém" (Amado, 2012: 232) ${ }^{21}$. Sin embargo y a pesar del deseo que el Sem-Pernas también siente, al igual que como lo hizo en la casa de doña Ester, cumple con la misión encomendada y facilita el robo: "Mas o roubo a enfurece. Porque pensa que Sem-Pernas só a amou nas noites longas de vícios para a furtar. Sua sede de amor humilhada" (Amado, 2012: 233) 22 . Esta vez, esa separación abrupta también afecta al Sem-Pernas. Él también desea a la solterona, también en su posición marginal necesita el afecto que temporalmente encontró en esa mujer.

\subsection{La excepcionalidad de Dora}

En consideración de la asimetría en la importancia de hombres y mujeres en los sucesos narrados, una primera línea de análisis será la importancia de la mujer en función de la conformación del hombre como sujeto político. En este caso Dora en relación de la formación de Pedro Bala como hombre, le permite remediar su infancia marcada por una condición marginal, empujándolo a tomar consciencia política de las causas sociales que generan que niños como ellos deban vivir en condiciones de precariedad y vulneración de cualquier tipo de derechos.

Sin duda, la mujer más relevante en la novela es Dora, la única niña que se integra a los Capitães da Areia. Antes de eso se narra su vida con su familia en el morro y se le describe de forma sexualizada: "Dora tinha treze para quatorze anos, os seios já haviam começado a surgir sob o vestido, parecia uma mulherzinha, muito séria, a buscar os remédios para a mãe, a tratar dela" (Amado, 2012: 163) $)^{23}$.

\footnotetext{
sexo en sus últimos latidos” (Amado, 1984: 246).

21 "Durante el día le responde mal, le dice brutalidades, ella llora. Le dice solterona, le dice que se va a ir. Ella le da dinero, le pide que se quede. Pero no es por el dinero por lo que se queda. Se queda por el deseo" (Amado, 194: 248).

22 "Pero el robo la enfurece. Porque piensa que el Sin Piernas sólo la amó en las largas noches viciosas para robarle. Su sed de amor está humillada" (Amado, 1984: 249).

23 "Dora tenía trece y andaba para los catorce y sus pechos ya habían empezado a brotar bajo el vestido. Parecía una mujercita, muy seria, en busca de remedios para la madre o aplicándoselos" (Amado, 1984: 176).
} 


\subsubsection{La orfandad que la impulsa al arenal}

Cuando muere su madre, debe hacerse responsable de su hermano pequeño como si ella fuera la madre. La varicela había matado a muchas personas en el cerro. Su madre se había enfermado, pero había mostrado mejoras hasta que volvió a enfermarse: "Trabalhou o dia todo, sob o sol e a chuva que caiu pela tarde. No outro dia não voltou ao trabalho porque recaiu do alastrime a recaída é sempre terrível. Dois dias depois descia do morro o último caixão feito pela varíola" (Amado, 2012: 164) ${ }^{24}$.

Esta muerte marca un cambio drástico en la vida de la niña, debe asumir las responsabilidades que antes eran de su madre: "Dora não soluçava. Corriam as lágrimas pelo seu rosto, mas enquanto o caixão descia ela pensava era em Zé Fuinha, que pedia o que comer. O irmãozinho chorava de dor e de fome" (Amado, 2012: 164) ${ }^{25}$. Ante esa nueva responsabilidad Dora quiere pedir ayuda en el lugar en que trabajaba su mamá. En el camino un policía la mira con deseo: "O guarda que a informou olhou para os seus seios que nasciam" (Amado, 2012: 165) ${ }^{26}$, que es lo mismo que le ocurre luego cuando logra llegar a la casa de doña Laura, esta vez es deseada por el hijo de la señora, mientras Dora les pide trabajo, en el rol de su madre, el único rol de mujer que conocía hasta el momento:

Ela explicou que queria falar com dona Laura, a patroa. A empregada a olhou com desconfiança. Mas o rapazola deixou de balançar a irmã e andou até o portão. Espiava os seios mal nascidos de Dora, os pedaços de coxas que apareciam sob o vestido. Perguntou:

$-\mathrm{O}$ que é que você quer?

- Eu queria falar com dona Laura. Sou filha de Margarida, que foi lavadeira dela... Não vê que ela morreu...

O rapaz não despregava os olhos dos seios de Dora. Era bonita a menina, de olhos grandes, cabelo muito loiro, neta de italiano com uma mulata (Amado, 2012: 165$)^{27}$.

\footnotetext{
24 “Trabajó todo el día, bajo el sol y la lluvia que cayó por la tarde. Al día siguiente no volvió al trabajo porque el mal había recrudecido y la recaída de varicela es terrible. Dos días después bajaba el morro el último ataúd debido a la varicela" (Amado, 1984:176).

25 "Dora no lloraba. Las lágrimas le corrían insensiblemente por la cara, pero mientras el ataúd bajaba pensaba en Zé Fuinha que pedía comida. El hermanito lloraba de dolor y de hambre” (Amado, 1984: 176). 26 "El policía que le dio información sobre el camino observó sus pechos nacientes" (Amado, 1984: 177).

27 “Le dijo que quería hablar con doña Laura, la señora. La empleada la miró con desconfianza. El muchacho abandonó la hamaca y se acercó a la puerta. Observó los pechos recién nacidos de Dora, las piernas
} 
El hijo de doña Laura en sus pensamientos imaginaba ser atendido por Dora como sirvienta y, en esa relación poder, hacer uso de una posición social superior para disfrutar de los favores sexuales que imagina de la niña: "O vento levantou um pouco o vestido dela. Ele teve pensamento canalhas ao ver o pedaço de coxa. Já se sonhava na cama, Dora trazendo o café pela manhã, a safadeza que se seguiria" (Amado, 2012: 166) ${ }^{28}$. Esto, sin embargo, no llegó a ocurrir, porque cuando Dora les contó que su madre había muerto por viruela no quisieron tener contacto con ella, lo que la llevó a buscar, junto a su hermano menor, suerte en la ciudad, lo que iniciará un recorrido en el que problematizará su posición de mujer en la sociedad.

Cuando Dora no logra conseguir trabajo, baja del morro a la ciudad con su hermano. Es invitada al arenal donde vivían los Capitães da Areia. Una vez allá se encuentra en medio de una discusión entre los niños que la deseaban: "Dora via o grupo avançar. O medo foi vencendo o desânimo e o cansaço em que estava. Zé Fuinha chorava" (Amado, 2012: 171) ${ }^{29}$. Su llegada al grupo genera discusiones porque nunca había habido una niña entre ellos, primero y al igual que el policía y el hijo de doña Laura, que la habían mirado con deseo, los niños del grupo discutieron por poseerla sexualmente, porque eso significaba jerarquía al interior del grupo, pero uno de los niños, João Grande, le echa en cara a Pedro Bala que no es una mujer sino una niña: "Eu sempre tive contigo, Bala. Sou teu amigo, mas ela é uma menina, fui eu e Professor que trouxe ela. Eu sou teu amigo, mas se tu vier eu te mato. É uma menina, ninguém faz mal a ela" (Amado, 2012: 172) ${ }^{30} \mathrm{y}$ a pesar de que Pedro Bala insiste, él se mantiene firme en su posición de defensa a Dora: "Não é uma puta, é uma menina, não vê que é uma menina? Ninguém toca nela" (Amado, 2012: $172)^{31}$. Esta defensa es clave, porque a pesar de que los Capitães da Areia tienen relaciones sexuales con otras niñas, las ven como mujeres que en su condición subalterna los satisfacen. Dora en cambio, al lograr ser vista como

que asomaban del corto vestido. Le preguntó:

-¿Qué desea?

-Yo quería hablar con doña Laura. Soy hija de Margarida, que fue lavandera de ella .. Se murió ...

El muchacho no quitaba los ojos de los pechos de Dora. Era una joven bonita, de ojos grandes, cabellera rubia, nieta de italiano y mulata" (Amado, 1984: 178).

28 "El viento levantó la falda de Dora. El muchacho tuvo pensamientos obscenos al ver los muslos. Ya soñaba con la cama, Dora trayéndole el café de la mañana, la lujuria que le seguiría" (Amado, 1984: 178).

29 "Dora vio avanzar al grupo. El miedo superó al desánimo y al cansancio que tenía. Zé Fuinha lloraba" (Amado, 1984: 184).

30 "Yo siempre estuve contigo, Bala. Soy tu amigo, pero ésta es una niña, yo y el Profesor la trajimos acá. Yo soy tu amigo, pero si te acercas te mato. Es una niña, no le hagáis nada" (Amado, 1984: 185).

31 "No es una puta, es una niña, ¿no ves que es una niña? Nadie la va a tocar” (Amado, 1984: 185). 
una niña les devuelve a ellos también su infancia, lo que remedia la situación marginal en la que estaban inmersos. También les ofrece colaborar con labores culturalmente femeninas, que ella aprendió de su madre: "Eu fico, ajudo vocês... Eu sei cozinhar, coser, lavar roupa" (Amado, 2012: 173) 32. Dora deja ver las carencias de los niños del trapiche, al convertirse en madre y hermana (Rossi, 2004: 191), roles que serán fundamentales en su paso por este grupo.

\subsubsection{La asimilación estética}

Dora que en un comienzo es tratada con deferencia por los demás niños, luego de un tiempo logra integrarse: "Dora integra-se definitivamente ao grupo quando troca o vestido por uma calça e passa a participar das atividades dos meninos, roubando e brigando" (Gómez, 1994: 32), también "é interessante notar como esta decisão de Dora é marcada pela inversão de seu vestuário" (Rossi, 2004: 192). Ambas citas refieren a la misma escena y leen con optimismo el momento en que Dora se cambia de ropa para formar parte del grupo. Esa lectura me parece incompleta, porque la integración a cambio de ocultar alguna de sus diferencias, en este caso el vestuario, sería una incorporación a medias e incluso una forma de invisibilización.

Se trata de una situación al menos curiosa, porque este travestimiento de Dora en niño para poder integrarse es en alguna medida una manera de negar sus diferencias como niña. Este gesto de silenciamiento de lo femenino tiene una justificación práctica, ya que, al vestirse como un niño deja de parecer una mujer sexualmente deseable. Recordemos que a su llegada al grupo su presencia se presentó como un punto de conflicto entre los niños que querían poseerla. En definitiva, los niños no resuelven en esa ocasión el tabú por el cuerpo femenino sexualizado, solo lo ocultan e integran a Dora como si fuera un niño. En la película de 2011, dirigida por Cecília Amado, nieta de Jorge Amado, cuando Dora aparece vestida con pantalones para aprender Capoeira es cuestionada por Pedro Bala, quien le dice que quiere volverse hombre, pero ella lo niega e incluso se burla de ellos diciendo que son un montón de niños creyéndose hombres. También le preguntan si va a fumar, porque para ser un hombre debe fumar, pero ella también señala que esa es una idea tonta, que ella no quiere ser un hombre, quiere ser como Rosa Palmeirão, de quien Professor le había hablado la noche anterior porque era valiente. Pedro Bala insiste preguntando si deben llamarla "Doro", a lo que ella agrega que a él le dicen "Bala" y que para ella Bala es mujer. Luego de eso, entre las risas de

\footnotetext{
32 “yo me quedo, los ayudo ... yo sé cocinar, sé coser, lavar la ropa” (Amado, 1984: 186).
} 
los demás niños que bromean señalando que al menos ahora uno de ellos va a ser bonito, Dora logra integrarse y participa del aprendizaje del capoeira. Es interesante que la película reformule esta escena, ya que permite actualizar la importancia de Dora como mujer, lo que no es explícito en la versión original de la obra.

Más allá de la escena antes mencionada, Dora luego sí se logra integrar al grupo en su diferencia de género, para lo que adopta roles culturalmente atribuible a las mujeres. Se convierte en hermana, en madre para algunos niños y en novia para Pedro Bala. Es distinta a otras niñas, logra formar parte del grupo.

Luciana Hoffmann Nunes advierte que en la adaptación al cine de la novela, Dora pasa de tener el cabello rubio a negro. Este, que podría ser un detaller anecdódico, es para Nunes la pérdida de un elemento fundamental para la funcionalidad simbólica de la relación entre los protagonistas, que representarían la unión de dos mundos en dos clases sociales:

A descrição física dos dois líderes (pólo feminino e pólo masculino) remete a possibilidade de trânsito entre a cidade alta (rica) e a cidade baixa (pobre) sem despertar preocupação a ninguém, o que auxiliava os roubos. Os dois personagens, dessa maneira, representam a ligação entre esses mundos, nos quais a cor da pele e o tipo de cabelo excluíam ou incluíam uma pessoa em um grupo social (2012: 9).

Pero lo negro no necesariamente configuraría una diferencia de clase, ya que lo negro en Brasil, más que configurar una categoría racial, constituye un símbolo proletario, tal como lo señala Rossi: "aquilo que o escritor entendeu por popular e proletário - como categorias intercambiáveis e ajustáveis uma a outra - o negro e o 'racial' apresentaram-se como uma espécie de 'objeto-tema' privilegiado, capaz de expressar as aspirações literárias e militante-partidária do escritor" (2004: 161). En ese sentido, la adaptación al cine de Cecília Amado estaría reforzando con el color del cabello de Dora su situación marginal después de la pérdida de sus padres, porque desde ese momento, estaba igual de sola que el resto de los niños que conformaban el grupo.

La llegada de Dora ocurrió después de la viruela. Aquí hay otra referencia femenina, porque esta enfermedad fue enviada por una diosa africana:

Omolu mandou a bexiga negra para a cidade. Mas lá em cima os homens ricos se vacinaram, e Omolu era um deus das florestas da África, não sabia destas coisas de vacina. E a varíola desceu para a cidade dos pobres e botou 
gente doente, botou negro cheio de chaga em cima da cama... como Omolu tinha pena dos seus filhinhos pobres, tirou a força da bexiga negra, virou em alastrim, que é uma bexiga branca e tola, quase um sarampo (Amado, 2012: $139)^{33}$.

La viruela había matado a uno de los niños, a los padres de Dora, enfermó al Boa Vida, aunque él sí logró regresar. Dora llega luego de la enfermedad y acoge maternalmente a esos niños abandonados, siendo solo una niña. Es por eso que se vuelve fundamental su presencia en el grupo. No es casual que la viruela, que provocó esta situación en la novela, haya sido enviada por Omolú, una diosa de las selvas de África, como aparecía en el fragmento anteriormente citado. Es la enfermedad en femenino, una herencia de las raíces africanas que cobra sentido en Brasil.

Hay un componente racial que hacía diferente a Dora, ya que ella era rubia y eso les llamó la atención desde el comienzo (recordemos que cuando se hablaba de la niña del arenal a la que Pedro Bala violó, las referencias a que fuera negra eran una característica fundamental en su sexualización): “João Grande e Professor iam na frente. Ambos tinham vontade de conversar com Dora, mas nenhum sabia o que dizer, não tinham se visto ainda num apuro assim. A luz das lâmpadas batia nos cabelos loiros dela" (Amado, 2012: 168) ${ }^{34}$.

\subsubsection{Remediar la marginalidad}

Por otro lado, desde el comienzo Professor y João Grande la miraron sin deseo sexual: "Mas não olhavam nem os seios, nem as coxas. Olhavam o cabelo loiro batido pela luz das lâmpadas elétricas" (Amado, 2012: 169) ${ }^{35}$. Precisamente esas características físicas de Dora le llaman la atención a Professor, porque la sitúan en una posición social diferente, aunque no tenga padres al igual que ellos ${ }^{36}$.

\footnotetext{
33 "Omolu mandó la viruela negra a la ciudad. Pero en lo alto los hombres ricos se vacunaron y como Omolu era una diosa de las selvas de África, no sabía nada de esas cosas de la vacuna. Y la viruela bajó a la ciudad de los pobres y enfermó a mucha gente, la puso negra y llena de llagas encima de las camas... como Omolu sentía pena por sus hijos pobres, le quitó fuerza a la viruela negra, la convirtió en varicela, que es una viruela loca y blanca, casi un sarampión”. (Amado, 1984: 149).

34 “João el Grande y el Profesor iban adelante. Los dos tenían ganas de charlar con Dora pero ninguno sabía qué decir, nunca se habían visto en un apuro así. La luz de la calle daba sobre los cabellos rubios de Dora" (Amado, 1984: 181).

35 “no le miraban ni los pechos ni las piernas. Sólo le miraban los cabellos rubios iluminados por la luz de las lámparas eléctricas” (Amado, 1984: 182).

${ }^{36}$ En la siguiente cita Rossi muestra como las características biológicas de Dora y su posición social están
} 
Professor fue el único personaje que encaró a Pedro Bala luego de la muerte de Dora, diciendo que él también la amó. ¿Qué tipo de amor era para estos personajes el respeto por la inocencia de Dora a diferencia de las otras niñas? Dora permite que estos niños que no se comportaban como niños recuperen por un tiempo su infancia y de ese modo logren crecer como adultos activos en el proyecto utópico de la novela.

El ejemplo más claro es lo que sucede con Pedro Bala, con quien tiene un romance infantil, donde primó el respeto y el cariño, lo que contrasta con la manera en la que Pedro Bala estaba acostumbrado a tratar a las niñas. Dora le muestra a Bala una manera diferente de amor, mucho más afectiva en vez de inmediatamente sexual o física:

Noiva. Antes que ela aparecesse ele nunca pensara nesta palavra: noiva. Gostava de derrubar negrinhas no areal. De encostar peito com peito, cabeça com cabeça, pernas com pernas, sexo com sexo. Mas nunca pensara em deitar na areia ao lado de uma menina, menina como ele, e conversar de coisas tolas e correr picula como os outros meninos, sem a derrubar para fazer o amor. Era outra maneira do amor, pensava numa confusão (Amado, 2012: 197) ${ }^{37}$.

Anteriormente hicimos referencia al contexto en el que aparece Capitães da Areia, a propósito del estudio comparativo que Luis de Melo Diniz realiza entre esta novela y Oliver Twist. Vale la pena mencionar la manera en que el autor entiende la presencia de las niñas que mueren como la reafirmación de que su presencia era instrumental para la preparación del héroe. En este caso es Pedro Bala quien se está preparando para la formación de una identidad revolucionaria ${ }^{38}$.

tensionadas en una pregunta sobre la su representación simbólica: "E era o que o mulato via. Os cabelos loiros eram carapinha rala, os olhos doces eram olhos achinesados da sertaneja, o rosto grave era o rosto sombrio da camponesa explorada. O verbo ser, conjugado no passado imperfeito (era), parece encerrar bem o limbo entre o que Dora apresenta de biológico (branca e loira) e social e simbólico (uma sertaneja mulata e explorada), sendo a última a imagem importante e reveladora dos sentimentos e da positividade de valores que os meninos e o narrador a revestem. De modo que, o texto deixa transparecer uma dimensão na qual ela 'é' e existe enquanto constituição física e orgânica, e uma outra, em que ela 'era', fruto da incorporação e apropriação simbólica efetuada a partir da relação afetiva e social que desenvolve no trapiche em que moram" (2004: 192).

37 "Novia. Antes de que ella apareciera en su vida no había pensado nunca en esa palabra: novia. Le gustaba tirarse negritas en el arenal. Acostarse pecho contra pecho, cabeza contra cabeza, piernas contra piernas y sexo contra sexo. Pero nunca había pensado en estar acostado en la arena con una muchacha, joven como él, y conversar sobre cosas tontas, sin montársela para hacer el amor. Era una manera diferente de amor, pensaba confundido" (Amado, 1984: 212).

38 "Nessa compreensão, procederemos a um cotejo entre a obra Oliver Twist do romancista inglês Charles Dickens, escrita no século XIX, e a narrativa, Capitães da Areia, do escritor brasileiro Jorge Amado, ressaltando a presença e a relevância da figura feminina nos bandos infantis. Tanto Nancy do bando de Fagin, 
La muerte de Dora cobra sentido en el crecimiento de Pedro Bala como un sujeto político. Gracias a ella pudo vivir una infancia de experimentación inocente, lo que le había sido negado al estar abandonado junto a otros niños, debiendo incorporar tempranamente prácticas de robo para sobrevivir a su entorno. El amor inocente que vive con Dora y que le permite crecer junto a ella, para convertirse en esposos justo la noche en que muere. Dora había remediado la falta de familia de estos niños, pero al fallecer deja a Pedro bala y a los demás Capitães da Areia otra vez en la indefensión. La solución es precisamente el proyecto utópico, en el que la lucha social le proporciona una familia:

acreditamos que a sua função estaria ligada, principalmente, ao crescimento intelectual e amadurecimento pessoal do herói. Ou seja, ela colabora para que Pedro Bala possa descobrir o amor como um sentimento verdadeiro; como entregar-se ao outro com afeto, e não apenas como o ato sexual cheio de furor, apenas pelo desejo, tal qual era imaginado pelos meninos do grupo. É a partir dessa descoberta, que Pedro Bala começa a entender que, muito além da violência, há outras formas de demonstrar suas insatisfações com a sociedade, ou de ajudar os seus amigos e companheiros. Assim inicia-se a sua participação, de forma ativa, nos movimentos sindicais, também como forma de dar continuidade à luta iniciada por seu pai, conforme se pode ver na terceira parte do romance (Diniz, 2009: 10).

Como señala Diniz, para el discurso de la novela de Jorge Amado, la muerte de Dora era necesaria, ¿qué habría pasado de otra forma? Su relación con Pedro Bala habría replicado la familia burguesa. También es importante que su muerte no aparezca atribuida a ninguna causa con demasiada claridad, solo se sabe que está enferma, que tiene fiebre, pero no qué enfermedad padece. Además, por la manera en que están presentados los acontecimientos es el orfanato, como una representación del Estado, lo que la enferma realmente: 
Um mês de orfanato bastou para matar a alegria e a saúde de Dora. Nascera no morro, infância em correrias no morro. Depois a liberdade das ruas da cidade, a vida aventurosa dos Capitães da Areia. Não era uma flor de estufa. Amava o

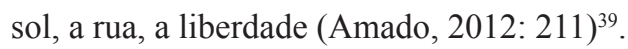

Dora se enfermó en el orfanato: "Tinha sempre febre, mas não dizia nada, porque odiava o silêncio da enfermaria, onde o sol não entrava e das as horas pareciam a hora agonizante do crepúsculo" (Amado, 2012: 211) ${ }^{40}$. En la novela no se aclara el mal que la aquejaba: "O médico que a vira balançara a cabeça com tristeza" (Amado, 2012: 211) ${ }^{41}$, pero a pesar de su delicada situación de salud, los Capitães da Areia la sacaron y la llevaron con ellos de vuelta donde estaba el grupo:

A Irmã murmurou:

- Ela está muito doente...

Dora respondeu:

- Eu vou, Pedro (Amado, 2012: 212) . $^{42}$

Dora sabía que estaba enferma, pero a pesar de eso prefiere irse con su familia sustituta, los Capitães da Areia: "Se atiraram por uma ladeira. Dora nem sentia a febre porque ia junto com Pedro Bala, ele pegando na sua mão" (Amado, 2012: 212) ${ }^{43}$. La alegría que sintió al volver a estar con los niños, no fue suficiente para contrarrestar la enfermedad, porque llegó muy enferma:

Os Capitães da Areia olham mãezinha Dora, a irmãzinha Dora, Dora noiva, Professor vê Dora, sua amada. Os Capitães da Areia olham em silêncio. A mãe-de-santo Don'Aninha reza oração forte para a febre que consome Dora

\footnotetext{
${ }^{39}$ Un mes de Orfelinato bastó para matar la alegría y la salud de Dora. Había nacido en el morro, y tuvo una infancia de correrías por él. Después la libertad de las calles de la ciudad, la vida aventurera de los Capitanes de la arena. No era una flor de invernadero. Amaba el sol, la calle, la libertad (Amado, 1984: 225). 40 "Siempre tenía fiebre, pero no decía nada, porque odiaba el silencio de la enfermería, donde el sol no entraba y todas las horas parecían la hora agonizante del crepúsculo” (Amado, 1984: 225).

41 "El médico que fue a verla movió la cabeza con tristeza” (Amado, 1984: 226).

42 "La hermana murmuró:

-Está muy enferma ...

Dora contestó:

-Yo voy, Pedro" (Amado, 1984: 226).

43 "Se largaron por una ladera. Dora ni sentía la fiebre porque iba junto a Pedro el Bala, tomados de la mano" (Amado, 1984: 226).
} 
desaparecer. Com um galho de sabugueiro manda que a febre se vá. Os olhos febris de Dora sorriem. Parece que a grande paz da noite da Bahia está também nos seus olhos (Amado, 2012: 213) ${ }^{44}$.

Dora había logrado ser una persona central en la vida de estos niños abandonados. En la cita anterior aparecen los roles vinculados a las mujeres que ella llegó a ocupar. Dora les permitió remediar su marginalidad, su abandono. Su muerte hacía incierto el futuro de estos niños: "os Capitães da Areia temem que isso aconteça. Então ficarão novamente sem mãe, sem irmã, sem noiva" (Amado, 2012: 214) ${ }^{45}$. Sin embargo, como vimos anteriormente, la muerte de Dora es importante para el crecimiento de los personajes. Es cierto que ella le permite a Pedro Bala vivir un amor infantil y con eso crecen juntos. La última noche que pasan juntos, antes de la muerte de Dora, ella dice que luego de haber estado en el orfanato ya es una mujer y quiere que él la haga su mujer: "Ela parecia não sentir a dor da posse. Seu rosto acendido pela febre se enche de alegria. Agora a paz é só da noite, com Dora está a alegria. Os corpos se desunem" (Amado, 2012: 215) ${ }^{46}$. En ese momento ambos dejan de ser niños.

Cuando Bala ya ha crecido, Dora muere, reforzando la idea de que es un personaje funcional al crecimiento de los niños del grupo: "A paz da noite envolve os esposos. O amor é sempre doce e bom, mesmo quando a morte está próxima" (Amado, 2012: 215) ${ }^{47}$. Pedro Bala la encuentra muerta en la madrugada: "Pedro põe a mão na testa de Dora. Fria. Não tem mais pulso, o coração não bate mais. O seu grito atravessa o trapiche, desperta os meninos" (Amado, 2012: 215) ${ }^{48}$. Lo siguiente es la manera en que entienden a Dora una vez muerta: "Mesmo tendo sido 'possuída', pouco antes de morrer, por Pedro Bala, como se tratou de um ato de 'puro amor', após sua morte, para os Capitães e para alguns dos amigos do grupo, Dora passa também a ser vista como

\footnotetext{
44 "Los Capitanes de la arena miran a la madrecita Dora, a la hermanita Dora, a la novia Dora; el Profesor ve a Dora, su amada. Los Capitanes de la arena miran en silencio. La mãe-de-santo Don’ Aninha reza una oración en voz alta para que la fiebre que consume a Dora desaparezca. Los ojos febriles de Dora sonríen. Parece que la gran paz de la noche de Bahía también está en sus ojos” (Amado, 1984: 227).

45 "los Capitanes de la arena tienen miedo de lo que pueda pasar. Entonces se quedarán de nuevo sin madre, sin hermana, sin novia" (Amado, 1984: 229).

46 "Ella parece no sentir el dolor de la posesión. Su cara encendida por la fiebre se llena de alegría. Ahora la paz es sólo de la noche, con Dora está solamente la alegría. Los cuerpos se separan” (Amado, 1984: 230).

47 "La paz de la noche envuelve a los esposos. El amor siempre es dulce y bueno, hasta cuando la muerte está cerca” (Amado, 1984: 231).

48 "En la madrugada... pone la mano sobre la frente de Dora. Fría. Ya no tiene pulso, el corazón no late. Su grito atraviesa el depósito y despierta a los muchachos" (Amado, 1984: 231).
} 
imaculada, e até mesmo como uma santa" (Diniz, 2009: 9). ¿Por qué cobra tanta importancia o qué características en vida la hicieron tan única? Precisamente que Dora sea una niña es lo que la hace la mujer más valiente de Bahía:

É verdade que Dora é a menina valente de quantas mulheres já nasceram na Bahia, que é a terra das mulheres valentes. Mais valente mesmo que Rosa Palmeirão, que deu em seis soldados, que Maria Cabaçu, que não respeitava cara, que a companheira de Lampião, que maneja um fuzil igual a um cangaceiro. Mais valente porque é apenas uma menina, apenas está começando a viver (Amado, 2012: 199) ${ }^{49}$.

Pedro Bala, quien tiene una relación muy estrecha con Dora, la única niña del grupo, parece experimentar una transformación enorme en su conformación de hombre gracias a ella. Dora, luego de volver del orfanato estaba enferma, pero antes de morir, convirtió a Pedro Bala en adulto: "Ela toma a mão dele, leva ao seu peito. Arde de febre. A mão de Pedro está sobre seu seio de menina. Ela faz com que ele a acaricie" (Amado, 2012: 215) ${ }^{50}$. Este paso de niño a adulto al tener una relación afectiva madura será lo que se consolide al asumir un rol social. Dora logra remediar la marginalidad de estos niños, la que antes solo había sido compensada a través del deseo y la experimentación sexual temprana. Ahora los niños ya crecieron y pueden tomar rumbos distintos. En el caso de Pedro Bala, ya está preparado para iniciarse en la actividad revolucionaria: "apesar de que lá fora era o terror, qualquer daqueles lares era um lar que se abriria para Pedro Bala, fugitivo da polícia. Porque a revolução é uma pátria e uma família" (Amado, 2012: 262) ) $^{51}$ Logra de esta manera subsanar su condición de niño huérfano, ya tiene una familia. Como ya hemos mencionado, la muerte de Dora prepara a Pedro Bala para la lucha proletaria que vendrá después. "a morte de Dora parece indicar o encaminhamento de Bala para sua efetiva militância, na medida em que perde o único sentimento de família que tivera na vida. Agora, nosso herói está desgarrado e livre para encontrar uma outra família: a proletária" (Rossi, 2004: 194). De esta forma buscará transformar el sistema que posibilita la existencia de la marginalidad.

\footnotetext{
49 "Dora se mostró más valiente que cualquier mujer nacida en Bahía, que es tierra de mujeres valientes. Más valiente que la misma Rosa Palmeirão que dio cuenta de seis soldados, que Maria Cabaçu, la que no se arredraba ante nadie, que la compañera de Lampião, que maneja un fusil igual que un cangaceiro. Más valiente porque es apenas una nena, apenas empieza a vivir" (Amado, 1984: 213).

50 "Ella le toma una mano y la lleva a su pecho. Arde en fiebre. La mano de Pedro se posa en su seno de niña. Ella hace que se lo acaricie" (Amado, 1984: 230).

51 "a pesar de que imperaba el terror, cualquiera de esos hogares se abriría para albergar a Pedro el Bala, fugitivo de la policía. Porque la revolución es una patria y una familia” (Amado, 1984: 283).
} 
Las afirmaciones sobre la trascendencia de Dora luego de su muerte son transversales a las diferentes creencias, ya sea en las palabras del padre José Pedro o en la mirada de las creencias afrodescendientes. Por ejemplo, Don' Aninha dice que se convertirá en santa: "Foi como uma sombra nesta vida. Vira santa na outra. Zumbi dos Palmares é santo dos candomblés de caboclo, Rosa Palmeirão também. Os homens e as mulheres valentes viram santo dos negros" (Amado, 2012: 216) (22 $^{52}$ también se dice que: "Foi como uma sombra para todos, um acontecimento sem explicação. Menos para Pedro Bala, que a teve. Menos para Professor, que a amou" (Amado, 2012: 216) . $^{53}$.

La trascendencia de Dora, a diferencia de las otras mujeres valientes de Bahía, también queda plasmada en las prácticas posteriores a su muerte: "Pirulito reza. Querido-de-Deus sabe o que esperam dele. Que leve o cadáver no seu saveiro e o jogue no mar, adiante do forte velho" (Amado, 2012: $216)^{54}$. Esto es, que entregue el cuerpo al mar: "Levam-na para a paz da noite, para o mistério do mar. O padre reza, é uma estranha procissão que se dirige na noite para o saveiro do Querido-de-Deus. Do areal, Pedro Bala vê o saveiro que se afasta. Morde as mãos, estende os braços" (Amado, 2012: 217) ${ }^{55}$.

Recordemos que Gayatri Spivak se pregunta si “¿puede hablar el sujeto subalterno?" Esta pregunta que en principio se responde negativamente, está trabajada por Spivak a nivel simbólico: la mujer, sujeto subalterno, logra hablar atentando contra sí misma; lo que es representado en relato del suicidio de Bhuvaneswari Bhaduri, que mencionamos anteriormente, quien se quita la vida mientras está menstruando para desprenderse del ritual que la mantenía sujeta a una tradición que la callaba. En esta novela no es declaradamente un suicidio lo que le quita la vida a Dora, pero sí ella se entrega a la muerte con tal de volver con los Capitães da Areia. Ella sale enferma del orfanato.

\footnotetext{
52 "Fue como una sombra en esta vida. Se hará santa en la otra. Zumbi dos Palmares es santo de los candomblés de los caboclos, Rosa Palmeirão también. Los hombres y las mujeres valientes se vuelven santos de los negros" (Amado; 1984: 231).

53 "Fue como una sombra para todos, algo sin explicación. Salvo para Pedro el Bala que la poseyó. Salvo para el Profesor que la amó" (Amado, 1984: 231).

54 “Pirulito reza. El Querido-de-Dios sabe qué esperan de él. Que lleve el cadáver en su saveiro y lo tire al mar, delante del fuerte viejo" (Amado, 1984: 232)

${ }^{55}$ La llevan hacia la paz de la noche, hacia el misterio del mar. El padre reza y es una extraña procesión la que se dirige hacia el saveiro del Querido-de-Dios esa noche. Desde el arenal, Pedro el Bala observa el barquito que se aleja. Se muerde las manos, extiende los brazos (Amado, 1984: 232)
} 
¿Qué aporte hace Dora a la discusión sobre la voz del sujeto subalterno? Con su muerte logra trascender de la misma manera en que los hombres valientes logran hacerlo, convirtiéndose en una estrella ${ }^{56}$, permitiendo que el sujeto femenino hable:

Contam no cais da Bahia que quando morre um homem valente vira estrela no céu. Assim foi com Zumbi, com Lucas da Feira, com Besouro, todos os negros valentes. Mas nunca se viu um caso de uma mulher, por mais valente que fosse, virar estrela depois de morta. Algumas, como Rosa Palmeirão, como Maria Cabaçu, viraram santas nos candomblés de caboclo. Nunca nenhuma virou estrela (Amado, 2012: 218) ${ }^{57}$.

Para la manera en que entendían el universo y la vida, solo importaba la creencia. Para ellos Dora se convirtió en una estrella:

Que importa tampouco que os astrônomos afirmem que foi um cometa que passou sobre a Bahia naquela noite? O que Pedro Bala viu foi Dora feita estrela, indo para o céu. Fora mais valente que todas mulheres, mais valente que Rosa Palmeirão, que Maria Cabaçu. Tão valente que antes de morrer, mesmo sendo uma menina, se dera ao seu amor. Por isso virou uma estrela no céu. Uma estrela de longa cabeleira loira, uma estrela como nunca tivera nenhuma na noite de paz da Bahia (Amado, 2012: 218) ${ }^{58}$.

¿Por qué es posible que en Salvador de Bahía se pueda entender la trascendencia de la manera en que ha sido narrada? Una respuesta posible es la importancia de la tradición religiosa afrobrasileña, porque las mujeres predominan en ella: "Nas religiões afro-brasileiras, particularmente, o sexo femi-

\footnotetext{
${ }^{56}$ En la novela de Clarice Lispector, La hora de la estrella, el personaje femenino también se encuentra en una situación de subalternidad. El gesto en el que logra cobrar voz es cuando muere y se convierte en una estrella, tal como sucede aquí con Dora "todavía no llegó la hora de estrella de cine en la que Macabea muera" (Lispector, 2001: 89). Aparece la posibilidad de ser estrella, la que le habían negado burlándose de su deseo.

57 "En los muelles de Bahía cuentan que cuando un hombre valiente muere se convierte en estrella del cielo. Así ocurrió con Zumbi, con Lucas de Feira, con Besouro, todos negros valientes. Pero nunca se vio el caso de que una mujer, por más valiente que fuera, se convirtiera en estrella después de su muerte. Algunas, como Rosa Palmeirão, como Maria Cabaçu, se habían vuelto santas en los candomblés. Pero ninguna se había vuelto estrella" (Amado, 1984: 233).

58 “QQué importa que los astrónomos digan que fue un cometa que pasó por Bahía esa noche? Pedro el Bala vio a Dora hecha estrella, yendo hacia el cielo. Había sido más valiente que todas las mujeres, más valiente que Rosa Palmeirão, que Maria Cabaçu. Tan valiente que antes de morir, aunque era una nena, se había entregado a su amor. Por eso se volvió estrella en el cielo. Una estrella de larga cabellera rubia, una estrella como nunca había tenido una noche de Bahía" (Amado: 1984: 233).
} 
nino parece ocupar uma posição de maior destaque em comparação às outras religiões" (Bastos, 2009: 156). Incluso, la mujer en estas prácticas religiosas ocupa un lugar más importante que los hombres, recordemos que la viruela fue traída por una diosa africana. Desde esa lectura es posible entender la muerte de Dora como la consagración de la niña en un ser divino por sobre las acciones de Pedro Bala y los otros Capitães da Areia.

La explicación de las prácticas descritas en la novela, que permiten que Dora ocupe el lugar sagrado que ocupa luego de su muerte, está en los roles de las mujeres en África. Bastos señala que la diferencia del rol de la mujer en la religión afrobrasileña es histórico. Las mujeres eran motivadas a ser autónomas, especialmente en lo económico (2009:163).

\section{Conclusiones}

En definitiva, podemos ver en esta novela que los problemas de la subalternidad en la pregunta por el género femenino están marcados por prácticas económicas, raciales y sociales, configurando espacios de libertad como también de sometimiento y violencia. Es así como la niña que es violada en el arenal encarna la vulnerabilidad por su posición social y su género; en cambio, los personajes de doña Laura y doña Ester tienen un espacio propio, el hogar que les permite tener una posición de poder, pero limitada a lo familiar y la maternidad, sin mostrar nunca la posibilidad del deseo sexual; en el caso de Dalva y la viuda a la que le roban, no ser madres ni tener esposos, además de tener un lugar propio que habitan, les permite mostrar deseos sexuales; finalmente Dora desde su niñez aporta en preparar a los Capitães da Areia al proyecto político y utópico en que se sostiene la novela para remediar la situación marginal y preparándolos para la revolución. Su presencia y muerte son entendidas a través de la cultura afrobrasileña y las prácticas culturales que le permiten brillar en el cielo como ninguna otra mujer lo había hecho.

Los Capitães da Areia antes de conocer a Dora ejercían prácticas abusivas sobre distintas mujeres para obtener beneficios sexuales y económicos, con los que validaban su masculinidad socialmente. Estas mujeres se encuentran aisladas y no poseen redes de apoyo y cooperación con otras mujeres. Luego de la aparición de Dora se produce un proceso evolutivo de los niños que son capaces de cederle un territorio que consideraban exclusivamente masculino, al integrarla al bando, no invisibilizando sus diferencias, sino que reconociendo un rol central que les permite remediar su condición marginal y avanzar en la conformación de una familia proletaria, en la que aunque con diferentes 
funciones, sus integrantes cooperan en el bienestar común. Dora es valiosa porque es niña, por eso es más valiente que las otras mujeres, por eso es superior. Hay algo en su infancia que la hace diferente.

Dora nunca llega a ser adulta, por lo que siendo niña logra contribuir en remediar las condiciones marginales en la que los Capitães da Areia estaban inmersos, como fue analizado. Los Capitães da Areia en su marginalidad buscaron compensar sus carencias a través del deseo sexual, incluso entre hombres, hasta que fueron instruidos en el juicio a ese tipo de identidades sexuales, como en la escena donde el Padre José Pedro le pide a Pedro Bala que eche a los niños que ocupaban el rol pasivo de la relación entre hombres. De esa forma se terminó ese periodo de suspensión de restricciones de género. Esa marginalidad luego fue remediada gracias a la figura de Dora, la única niña que se integró al grupo y que se convirtió en hermana, madre y amante, permitiéndoles a los niños a través del artificio de la familia la reparación de sus carencias. Permite que estos niños que se esforzaban por ser hombres a temprana edad, vuelvan a ser su infancia y crezcan en un entorno familiar que crearon. Esa familia, es la familia proletaria por la que se debe luchar. Los niños luego de la muerte de Dora pudieron crecer en sus desarrollos personales, no necesariamente integrándose a la sociedad. De entre el grupo destaca el proceso de Pedro Bala, que se vuelve un huelguista como su padre, desde donde pretende transformar las desigualdades sociales que experimentó siendo solo un niño.

\section{Referencias bibliográficas}

Amado. C. (2011). Capitães da areia. Imagem Filmes. DVD.

Amado, J. (2012). Capitães da Areia. São Paulo: Companhia das letras.

Amado, J. (1984). Capitanes de la arena. Trad. Estela Dos Santos. Madrid: Alianza Editorial.

Arend, S. F. (2012). “Trabalho, escola e lazer” en Nova historia das mulheres no Brasil. Organizadoras Carla Bassanezi Pinsky y Joana Maria Pedro. São Paulo: Contexto.

Arend, S. F. (2012). "Trabalho, escola e lazer" en Nova historia das mulheres no Brasil. Organizadoras Carla Bassanezi Pinsky y Joana Maria Pedro. São Paulo: Contexto.

Armstrong, N. (1991). Deseo y ficción Doméstica. Trad.María Coy. Madrid: Cátedra. 
Azevedo, C. A. (1983). "Literatura \& praxis social no Brasil: O romance nordestino de 1930”. Revista de Crítica Literaria Latinoamericana $\mathbf{N}^{\circ} \mathbf{1 7}$ : $89-104$.

Bastos, I. S. (2009). "A visão do feminino nas religiões afro-brasileiras". CAOS - Revista Eletrônica de Ciências Sociais $N^{\circ}$ 14: 156 - 165.

Brivio, G. (2005). "Representações sobre a prostituição feminina na obra de Jorge Amado: um estudo estatístico" Tesis para optar al grado de Mestre em Estudos Interdisciplinares sobre Mulheres, Gênero e Feminismo. Salvador de Bahía Universidade Federal da Bahia. 250 pp.

Cândido, A. (1989). "A revolução de 30 e a cultura". En su A educação pela Noite e outros ensaios. São Paulo: Ática.

Cândido, A. (2007). "O direito à literatura". En Vários escritos. São Paulo: Duas Cidades/ Ouro sobre Azul.

De Lauretis, T. (1996). "La tecnología del género" (Trad. Ana María Bach y Margarita Roulet). Mora N ${ }^{\circ} 2:$ 6-34.

Diniz, L. (2009). "A criança oprimida na literatura: A presença feminina nos bandos infantis em Oliver Twist de Charles Dickens e Capitãis da Areia de Jorge Amado". Paraíba: II Seminário Nacional sobre Gênero e Práticas Culturais.

Federici, S. (2015). Calibán y la bruja. Mujeres, cuerpo y acumulación originaria. Trad. Verónica Hendel y Leopoldo Sebastián Touza. Buenos Aires: Tinta Limón.

Gomes, V. T. (2005). "O bando como a família possível: leitura plural de capitães da areia de Jorge Amado" Tesis para optar al grado de Mestrado em Família na sociedade contemporânea. Salvador de Bahía: Universidade Católica do Salvador. 98 pp.

Gómez, A. C. (2002). Capitães da Areia. Jorge Amado. São. Paulo: Ática, 1994.

Landes, R. (2002). A cidade das mulheres. Trad. María Lúcia do Eirado Silva (Original The city of women). Rio de Janeiro, Ed. UFRJ.

Lispector, C. (2011). La hora de la estrella. Trad. Gonzalo Aguilar. Buenos Aires: Corregidor. 
Nunes, L. H. (2012). “A capitã da areia: como a personagem Dora do romance Capitães da areia, de Jorge Amado, é personificada no filme homônimo de Cecília Amado" II Jornada UFRGS de Estudos Literários universidade federal do rio grande do sul: 1-15.

Rossi, L.; Freitas G. (2004). “As cores e os gêneros da revolução”. Cadernos Pagu $N^{\circ} 23: 149-197$.

Scott, A. S. (2012). "O Caleidoscópio dos arranjos familiares" en Nova historia das Mulheres no Brasil. Organizadoras Carla Bassanezi Pinsky y Joana Maria Pedro. São Paulo: Contexto.

Spivak, G. Ch. (2009). “¿Pueden hablar los subalternos?”. Trad. Manuel Asensi Pérez. MACBA: Barcelona. 
